\title{
ПЛАСТИКА МАЛИХ ФОРМ У ТВОРЧОСТІ ТАРАСА ЛЕВКІВА: ХУДОЖНЬО-СТИЛЬОВІ ОСОБЛИВОСТІ
}

\begin{abstract}
Дослідження присвячено творчості відомого сучасного львівського мития Тараса Левківа, яскравого представника мистецької еліти України. Проведено аналіз низки джерел, пов'язаних з особливостями художньо-критичного осмислення складних творчих прочесів, притаманних для Тараса Левківа. Наголошено на актуальності скульптури у створенні цікавих образів, які мають глибоке філософське звучання та неабиякий резонанс у сучасному кризовому суспільстві.

Увагу акиентовано на домінуванні широкого спектру ідей у творчості майстра. Доведено, щзо творчий доробок мития у кераміці великий кількісно та глибокий ідейно та складно піддається простій класифікації, проте з деякою умовністю ми спробували зробити такий поділ. Насамперед виділено пластику малих форм з антропоморфними мотивами. Зазначено, щьо важливе місие займає пластика малих форм в основу якої покладено куб, ичліндр. Також виділена група скульптури малих форм, в основі композиційної побудови якої лежить куля або округлість овоїдної форми. Зазначені найпростімі геометричні форми є улюбленими та домінантними у пластиці малих форм мития. Зосереджено увагу на такій класифікації творів, яка здебільшого не вичерпує обсягу творчого доробку автора.

Мета статті - дослідити художні особливості окремих творів кераміки відомого сучасного львівського художника Тараса Левківа. У межах статті відповідно до поставленого завдання найбільшу увагу приділено пластиці малих форм, створених автором, починаючи з 60-х років XX століття та протягом усього творчого шляху. Наукова новизна: вперше проаналізовано та класифіковано скульптури малих форм відомого львівського художника Тараса Левківа.

Своїми творчими роботами Тарас Левків авторитетно декларує про те, щчо дух править світом, утворюючи відносно самостійну ідеальну субстаниію. Властивості творчості, в основу якої покладено філософське розуміння буття, виражені в особливій художній формі, вони є унікальним, найефективнішим способом розуміння. Тарас Левків намагається відтворити результат свого пізнання дійсності в індивідуальній, конкретно-чуттєвій образній формі. Художник відтворює життя, реальність такою, якою ї̈ сприймають намі органи чуття, тобто у всьому багатстві ї̈ різномаїтих властивостей і поясненнях світу, які є особливим способом комунікацїі з глядачем.
\end{abstract}

Ключові слова: скульптура, скульптура малих форм, творчість, художній образ, художні особливості.

Volodymyr HONCHARUK, orcid.org/0000-0002-2687-3956

Senior Lecturer at the Department of Monumental Sculpture

Lviv National Academy of Arts

(Lviv,Ukraine)Vovamds@ukr.net

\section{PLASTICS OF SMALL FORMS IN THE CREATIVITY OF TARAS LEVKIV: ARTISTIC AND STYLE FEATURES}

The article is devoted to the study of the works of the famous contemporary artist Taras Levkiv from Lviv, a bright representative of the artistic elite of Ukraine. An analysis of a number of sources related to the peculiarities of artisticcritical understanding of complex creative processes inherent to Taras Levkiv was conducted. Emphasis is placed on the relevance of sculpture in creating interesting images that have a deep philosophical sound and a great resonance in modern crisis society. Importance is placed on the dominance of a wide range of ideas in the work of the master and the means of reproducing the inner world of the heroes.

It is proved that the creative work of the artist in ceramics is plentiful and ideologically deep is difficult to easily classify, but we made an attempt to make such a division with some conventionality. First of all, are distinguished plastics of small forms with anthropomorphic motifs. It is noted that an important place is occupied by plastic of small shapes based on a cube, cylinder and other geometric shapes. The following group of sculptures of small forms in its basis of compositional construction has a sphere or roundness of an ovoid form. 
It is worth noting that the mentioned simplest geometric shapes are favorite and dominant in the plastic of small forms of ceramics of the artist. This article focuses on such a classification of works, which usually does not cover a wide range of creative work of the author. The aim of the article is to study the artistic features of individual works of ceramics of the famous modern artist Taras Levkiv from Lviv. In this article, in accordance with our task, the greatest attention is paid to the plastics of small forms, created by the artist since the 60s of the twentieth century and throughout the creative path.

Scientific novelty: The analysis of sculpture of small forms of the known artist Taras Levkiv from Lviv was carried out and conducted for the first time. A series of works authoritatively declares that the spirit rules the world, forming a relatively independent ideal substance. Features of creativity, which is based on a philosophical understanding of life, expressed in a special art form is a unique, most effective way of understanding. Taras Levkiv tries to reproduce the result of his knowledge of reality in an individual, specifically-sensaul figurative form. The artist recreates life and reality the way it is perceived by our senses, that is, in all the richness of its various properties and explanation of the world, which is a special way of communicating with the viewer.

Key words: sculpture, sculpture of small forms, creativity, artistic image, artistic features.

Постановка проблеми. Тарас Левків є помітним представником мистецької еліти України. Його роботи широко відомі і на батьківщині, і за кордоном. Вони характеризуються пластичною довершеністю, лаконізмом, виразною художньою мовою та особливим мистецьким почерком, який передає чітку життєву позицію автора. Творчість Тараса Левківа має примітну особливість, оскільки зміст його робіт і їх композиційне рішення потребують мислення глядача, тобто співтворчості. Відомого кераміста цікавлять не лише факти і події, як це було в період соцреалізму, а філософський сенс буття людини, її трепетний зв'язок із навколишнім світом, іiі духовне наповнення. Звідси алегоричність та багатозначність творів Тараса Левківа.

На кількох сторінках не можливо описати весь талант Тараса Левківа, творчістю якого захоплюються і на рідній землі, і за межами України. У статті акцентовано увагу на великому пласті сучасної кераміки Львова, частиною якого $\epsilon$ творчий доробок сучасника. Робота виконана відповідно до підготовки наукових кадрів Львівської національної академії мистецтв та згідно 3 науково-дослідними роботами кафедри теорії та історії. Окремі дослідження виконані автором як допоміжний матеріал до розділу «Пластика малих форм у посттоталітарному творчому середовищі Львова», який опрацьовується відповідно до затвердженої теми дисертації «Львівська скульптура малих форм другої половини XX - початку XXI століття» у Львівській національній академії мистецтв (Нора, 2014; Турчак, 2008).

Аналіз останніх досліджень. В українському мистецтвознавстві віднедавна простежується посилений інтерес до скульптур малих форм, які стали предметом дослідження сучасних авторів (Винниченко, 2010; Голубець, 2020; Голубець, 2007; Дуда, 2009; Придатко, 2011).

Розвиток скульптур малих форм Львова в контексті новітніх досліджень $€$ прикладом загальних тенденцій, які здебільшого виокремлюють вітчиз- няний мистецтвознавчий дискурс. Творчість відомого скульптора відтворено в альбомах, які вийшли друком 2005, 2007, 2009 років (Голубець, 2007; Дуда, 2009; Левків, 2011; Придатко, 2011).). У вступній статті відомий львівський мистецтвознавець О. Голубець високо оцінив творчість свого сучасника (Винниченко, 2010: 4-9). У його монографії «Магія третього виміру. Скульптурна пластика кінця XIX - початку XXI століття» в контексті скульптури Львова кінця XX - початку XXI століття досліджено мистецьке середовище, в якому живе і працює Тарас Левків (Голубець: 122-125]. Недостатня та фрагментарна оглядовість творчості митця у спеціальній літературі потребує аналізу і творів скульптора, і способів творчого мислення, і художніх процесів та явищ загалом.

Мета статті - дослідити творчість відомого сучасного львівського художника Тараса Левківа. Умежахстаттівідповіднодопоставленогозавдання найбільшу увагу приділено пластиці малих форм, створених автором, починаючи із $60-\mathrm{x}$ років $\mathrm{XX}$ століття та протягом усього творчого шляху.

Виклад основного матеріалу. Алегорична, символічна, багатоголоса кераміка цього великого майстра епічна та монументальна. У багатьох творах відчувається суперечність між реальним навколишнім світом і думкою автора. Творчий доробок митця у кераміці великий кількісно та глибокий ідейно складно піддається простій класифікації, проте з деякою умовністю ми спробуємо зробити такий поділ. Насамперед варто виділити пластику малих форм з антропоморфними мотивами. Важливе місце займає пластика малих форм, в основу якої покладено куб, циліндр. Є група скульптур, в основі композиційної побудови яких маємо кулю або округлості овоїдної форми. Варто зазначити, що вказані найпростіші геометричні форми є улюбленими та домінантними у пластиці малих форм кераміки митця.

У цій статті зосереджено увагу на такій класифікації творів, яка не вичерпує широкого діапазону творчого доробку автора. Почнемо $з$ аналізу 
та характеристики пластики малих форм 3 антропоморфними мотивами. Творчі роботи Тараса Левківа занурюють в епоху героїв билин, час Київської Русі, який постає перед нами як надто величне і значуще. До праць, які належать до раннього періоду творчості, відноситься декоративна ваза «Військо галицьке» (1963 рік), декоративний пласт «Русичі» (1967 рік), декоративна статуетка «Дідугани» (1968 рік). В історичних образах зображено нескінченний світ доби Київської Русі. Він таємничий, $з$ біллю та сумнівами, з безмежним прагненням до добра та істини. У скульптурі «Сліпа» (1964 рік) цілком передано трагізм ситуації, в якій автор відображає горе не конкретної людини, а «сліпоти» як ідеї, яка часто присутня серед людей та у суспільстві загалом.

У декоративних вазах «Дівчина» (1969 рік), «Чубата» (1972 рік), «Химера» (1969 рік) художня виразність виробів виявляється в гармонійному й органічно узгодженому поєднанні основної антропоморфної форми та багатьох дрібних мотивів рельєфного орнаментального декору. У декоративних вазах чітко простежуються стилізовані 3 делікатним натяком жіночі форми. Загалом декоративні вази сприймаються композиційно завершеним твором, вирізняються пластичністю, м'якою декоративністю і за необхідності готовністю виконувати конкретне функціональне призначення.

Декоративна скульптура «Чугайстер» (1969 рік) представляє міфологічного персонажа народної поезії Карпат. За переказами це волохатий житель лісу в білому одязі з блакитними очима, який приязно ставиться до людей. Про великого лісового бога жителів Карпат, на жаль, маємо дуже мало наукових публікацій, лише поодинокі етнографічні записи. У власному творчому баченні Тарас Левків представив Чугайстра замисленим i поважним, із густими опущеними бровами та довгими вусами, як захисника та охоронця подорожуючих, які заблукали. Лаконічні стилізовані постаті маленьких людей у центрі міфологічного героя зображено без рук, що підкреслює їх безпорадність, натомість великі широко розкинуті руки Чугайстра та крислатий одяг півколом свідчать про опіку та захист від ймовірної небезпеки.

I за загальною формою, і за пластикою дрібних деталей, заглиблюючись у сутність і розкриваючи характер міфологічного прообразу, автор вдало підпорядковує деталі у цілісну завершену форму. Декоративні статуетки «Хор» (1968 рік), «Троїсті музики» (1969 рік) та «Оркестр і диригент» (1972 рік) схожі за манерою та стилістикою виконання. Цими працями Тарас Левків стверджує широкий діапазон трактування та складність розуміння української народної музики.
Співочість і мрійливість, яка притаманна українцям, на повну силу звучить у ритмічних гармонійних постатях. Видовжені форми циліндриків доповнені дрібними елементами рис обличчя та рук. Національні відзнаки українця простежуються в елементах одягу, моделі головного убору, формі зачіски та способі носити вуса. Однаковий композиційний підхід у вирішенні постатей, виконаних на гончарному крузі, підкреслює ідею монолітності та єдності українців, ідею єдиного пориву в час смутку та радості.

Подібними за стилістикою виконання є декоративна скульптура «Фестиваль» (1978 рік) та «Отара» (1978 рік). Композиція скульптур розгортається навколо ідейного центру, в якому пастух отари з відчуттям гідності та достоїнства пасе своїх овечок. Майже кругла форма тваринок додає відчуття спокою, добра та впевненості у завтрашньому дні. Аналогічні за композиційною побудовою округлі форми співаків у декоративній скульптурі «Фестиваль». Твори Тараса Левківа «Чугайстер», «Козак б'є в литаври», «Троїсті музики» були своєрідними символами часу. Апогеєм та ідейним завершенням цього періоду можна вважати дипломну роботу «Енеїда» (1971 рік) (Голубець, 2007: 7).

Про ранній період творчості відомий сучасний дослідник Орест Голубець зазначає, що наприкінці 1970 року у Львові відбулася унікальна подія - персональна виставка студента Тараса Левківа. Представлені ним твори розкрили нові можливості давньої техніки гончарного круга. Нестримні пластичні фантазії трансформували природні форми та явища, предмети і людські фігури. Оригінальні композиції здебільшого торкалися національної тематики, містили виразні ознаки етнографізму, виражали характерні для народного мистецтва оптимізм і гумор, які в умовах тоталітарного суспільства мали важливе значення (Голубець, 2007: 6-7).

Нехтуючи застарілими нормами і догмами, Тарас Левків віддав перевагу власному розумінню процесів, які відбувалися у суспільстві, своїй образній системі, основу якої творять лаконізм і зосередженість образів, втілених у складних і виразних композиційних формах. Звернення Тараса Левківа до джерел національної культури, пізнання самобутнього світу іiі образів визначило стилістичну різноманітність кераміки, відкрило нові шляхи для розвитку творчої думки.

Декоративна композиція «Безконечні дороги» (2007 рік) та «Хлопчик на хвилі» (2007 рік) розкривають тему пошуку та правильного вибору, зв'язок поколінь, саме ті морально-етичні засади, які притаманні українській етнопедагогіці. 
«Парад планет» (2009 рік) вражає темою та сюжетом композиції, демонструє глядачу місце людини у безмежному світі. Художник представив нам людину замислену, стурбовану, яка не домінує в хаосі сьогодення, а підпорядкована споконвічним ритмам природи та традиційним укладам існування. Основною є ідея співпереживання за долю планети та місце людини у цьому світі.

Про творче зростання та формування власного мистецького почерку Тараса Левківа зазначає Орест Голубець: «Віддаючи належне таким вродженим якостям як наполегливість і працьовитість, можемо стверджувати, що Тарасу Левківу до певної міри поталанило. Адже становлення його творчої особистості відбувалося в бурхливий і короткотривалий, як спалах, період національного відродження - час «шістдесятників». В умовах тодішньої «відлиги» львівська кераміка відіграла головну роль, об'єднала значний творчий потенціал, який розкрився гроном непересічних індивідуальностей, сприяла збереженню засад вільної, незаангажованої творчості. Важливою в житті молодого митця була зустріч із педагогом, який дав йому ключ до глибокого розуміння і зацікавленого філософського осмислення багатьох природних і мистецьких явищ, - Тарасом Драганом. Їхнє спілкування перетворилося в багаторічну духовну близькість і справжню дружбу (Голубець, 2007: 6).

Згодом для Тараса Левківа відкрилися нові можливості та перспективи - презентація власних творчих робіт на міжнародних і всесоюзних симпозіумах художньої кераміки. У своїх дослідженнях Орест Голубець зазначає, що на творчій базі у Дзінтарі (Латвія), куди Тарас Левків потрапив першим зі Львова, відбулося його знайомство 3 видатним і шанованим у світі митцем і педагогом - Петерісом Мартінсоном, що мало важливий вплив на формування творчості молодого майстра. Це важливе знайомство переросло у взаємну приязнь, сприяло активному розширенню кругозору та формуванню нових ідей, швидкому опануванню нових матеріалів і технологічних можливостей, відчуттю впевненості у своїх силах (Голубець, 2007: 7). Почався новий період творчості Тараса Левківа, який можна означити свободою мислення, сміливими експериментами у сфері вільного формотворення, яке офіційно було заборонене у скульптурі радянського періоду.

Чималу кількість творчих робіт Тараса Левківа становлять праці, композицію яких формують кулі, кола та овоїдні форми (Голубець, 2007: 9). У цьому простежуються очевидні аналогії з виразним розумінням простору, яке властиве для кубізму. Тематично композиції такого плану пов'язуються 3 пей- зажними мотивами (Голубець, 2007: 9-10). До таких 3 раннього періоду творчості автора відносяться декоративна статуетка «Кактус» (1969 рік), декоративна композиція «Квітка» (1974 рік), декоративна композиція «Верба» (1978 рік), декоративна пластика (1970 рік), декоративна композиція «Вишні» (1975 рік), декоративна композиція «Велика сім'я» (1981 рік), декоративна композиція «Пам'ятник килимару» (1984 рік).

Тарас Левків і за загальною формою, і за пластикою дрібних деталей, заглиблюючись у сутність і розкриваючи характер кожного образу, вдало підпорядковує деталі у цілісну завершену форму. Творчі роботи, в основу яких покладена куля та кругоподібні форми, передають широкий діапазон трактування образу Землі, Сонця, Місяця як небесних сакральних об'єктів, складного філософського розуміння образів, ідеограм та ідей істини, досконалості, довершеності.

Робота «Застиглі хвилі» (1994 рік) вражає лаконізмом, вишуканою сріблясто-блакитною кольоровою гамою та ритмом пучка прокреслених ліній, які м'яко лягають по формі хвилі. Близькою за звучанням є декоративна композиція «Тінь» (1978 рік), декоративна композиція «Сонячний день» (1979 рік). Декоративна композиція «Колосок» (1978 рік) відноситься до раннього періоду творчості митця. Вона вражає енергією звучання наповненого зрілого колосу, силою форми та декору, що підкреслено теплою охристою кольоровою гамою виконання. Виконана на гончарному крузі, декорована ангобами композиція $\epsilon$ близькою до сприйняття та розуміння, оскільки відображає фундаментальні архетипи українця, пов'язані з ідеями відродження та життя.

У 1972 році Тарас Левків став першим представником від України (серед п'ятьох від тодішнього СРСР) на III-му міжнародному бієнале у Валлорисі (Франція), де з 1945 року у кераміці періодично працював знаменитий Пабло Пікассо. У подальші роки Тарас Левків отримував почесні дипломи конкурсів художньої кераміки у Фаєнці (Італія; 1974, 1978, 1979, 1980 роки). Участь художника в таких престижних акціях стала можливою завдяки персональним запрошенням, отриманим із Москви: столичні спеціалісти змушені були толерувати формальні пошуки і представляти мистецтво радянських народів за кордоном, створювати там ілюзію «вільного» творчого процесу (Голубець, 2007: 11-12). Така ситуація викликала відверте роздратування у київських керівних структурах, де професійному декоративно-прикладному мистецтву відводилася місія копіюванння і «вдосконалення» народних традицій. 
Орест Голубець, поважний дослідник скульптури того періоду, у вступній статті до альбому «Тарас Левків: кераміка, графіка, інтарсія» (2007 рік) зазначає, що недаремно персональна виставка Тараса Левківа у столиці радянської України Києві в 1979 році опинилася на межі закриття. Висловивши своє негативне враження, «ідеологічні цензори» все-таки не наважилися заборонити вернісаж, проте у пресі незабаром з'явилася стаття під назвою «Збочивши на манівці», в якій творчий доробок митця зазнав нищівної критики (Голубець, 2007: 12).

В окрему групу можна віднести твори раннього періоду творчості, які представляють тему космосу та екології, в яких художник наче покидає буденний світ і звертається до вищої логіки та порядку: декоративна скульптура «Північне сонце» (1977 рік), декоративна композиція «Подільська осінь» (1977 рік), декоративна композиція «Нічна квітка» (1978 рік) декоративна композиція «Весна» (1974 рік), «Кам’яні вихори» (1980 рік), декоративна композиція «Тихий сніг» (1983 рік), декоративна композиція «Космічна археологія» (1984 рік), декоративна пластика «Обережно-крихке!» (1984 рік), «Космічий спрут» (1987 рік), «Реставрація планети» (1988 рік).

Ці творчі роботи майстра об'єднують спільні характеристики: куля як основа композиційнопластичного вирішення, яка особливо вдало розкриває ідею досконалості природи та буття людини; сріблясто-біло-блакитна кольорова гама доповнена мінімальним декором, вона використана особливо майстерно та точно передає космічні вібрації вічних природних ритмів. Споглядання цих творів $\epsilon$ високодуховним складним психологічним процесом, який максимально гармонізує внутрішній стан, оскільки пропонує наблизитися і навіть долучитися до вічних ритмів існування та буття.

Ідея передана мовою потужного символу i якнайкраще задовольняє емоційну сферу особистості, що призводить до порядку та досконалості. Декоративну пластику «Північне сонце» представляє оранжево-охриста блискуча куля, яку ніби намагаються розчавити дві масивні півкулі, вкриті згустками білої емалі. Лаконічними і виразними засобами Тарас Левків відтворює безсилля життєдайного тепла проти суворої та холодної вічності снігів (Голубець, 2007: 11).

Орест Голубець у своїй останній монографії, яка недавно вийшла друком, «Магія третього виміру. Скульптурна пластика кінця XIX - початку XXI століття» (2020 рік), аналізуючи мистецьке середовище Львова в умовах тоталітарного режиму, зазначає, що спротив ідеологічному пре- сингу у сфері скульптури у Львові мав певну специфіку. Поряд зі стилістикою соцреалізму, впровадженою приїжджими художниками в роки становлення радянської влади, у другій половині 1960-х років сформувався особливий підхід до трактування скульптурної маси. Він передбачав значне узагальнення, геометризацію об'ємів, розташування їх у просторі на основі акцентованого протиставлення рельєфу і контрельєфу. Очевидно, що в такому випадку могли виникати певні аналогії 3 новаторськими принципами формотворення О. Архипенка, хоча офіційно львів'яни їх не декларували (Голубець, 2020: 65-66).

Конструктивно-кубістичні тенденції у працях львівських скульпторів були спробою певного руху в бік модерної форми, своєрідним прихованим зовні «півкроком» (Голубець, 2020: 66). У своїх роздумах Орест Голубець зазначає, що на початку 1960-х років у Львові зародився особливий різновид скульптурної пластики, безпосередньо пов'язаний зі специфікою місцевого навчального закладу, в якому виразно домінувало декоративно-ужиткове мистецтво. 3 погляду тоталітарного режиму воно займало «периферійні» позиції і не могло втілювати «головні» ідеологічні завдання. Завдяки такій «другорядності» ця зона не підлягала жорсткому контролю і поступово перетворилася в епіцентр вільної творчості - на своєрідну «територію порятунку» від насаджуваних постулатів соцреалізму. Першими на шлях таємного спротиву стали керамісти. Об'ємнопросторові об'єкти знаного львівського митця Тараса Левківа впритул наблизилися до абстрактної пластики (Голубець, 2020: 66].

Тема істини, яка в художньо-композиційній формі кулі представляє ідею найбільш досконало, продовжилася у творчості Тараса Левківа й у більш зрілому віці. Декоративна пластика «Степ» (1994 рік) вишукано, легко, у світлій молочно-золотавій кольоровій гамі оспівує ідею степу та рідної землі. Тему суспільства та подій у ньому віддзеркалює декоративна композиція «Колесо історії» (2006 рік). Декоративна пластика «Архітектурна хвиля» (2002 рік) у доробку Тараса Левківа є особливою, оскільки композиційно просторове рішення поєднує форму кола та куба, таких зрозумілих для автора.

Декоративна пластика «За горами гори» (2002 рік), декоративна пластика «Планетарний пояс» (2005 рік) і декоративна пластика «Розломи» (2003 рік) за темою споріднені і вирізняються високою культурою виконання, низкою композиційних знахідок. Автору вдалося простими і доцільними засобами, уникаючи зайвих 
реалістичних підходів, відтворити в несподіваній для цього сюжету техніці яскравий образ з глибоким ідейним значенням.

Важливе місце займає пластика малих форм, в основу якої покладено куб, циліндр та інші геометричні форми. Як первісна ідеограма, семантичне значення має квадрат. Як і хрест, він $є$ основним символом числа чотири, яке може позначати землю, цілісність, повноту та справедливість. Квадрат також символізує чотири сторони світу, чотири фази буття (ранок, день, вечір, ніч), чотири стіни, а також дитинство, юність, зрілість і старість. Ця геометрична фігура - образ сакрального простору, впорядкованого і захищеного з усіх сторін.

У творах, які ми розглянемо, ця ідея має домінантне значення. Робота «Проростання» (1995 рік), декоративна пластика «Біломорканал» (1999 рік), декоративна композиція «Жнива» (1998 рік), декоративна композиція «Лінія» виконані технічно досконало і несуть у собі філософію порядку буття та вічність узгодженості ритму людини та нествореного нею світу. Вражає силою звучання та простотою композиційного рішення декоративна пластика «П'ядестал для тирана» (1995 рік), у якій вдало продуманими пропорціями автор композиційною лаконічністю та недосказаністю на весь голос волає про найстрашніші історичні моменти нашого народу. Саме такий принцип недосказаності поєднаний 3 композиційною виразністю форми $є$ могутнім акордом і поштовхом до енергії думки глядача.

Декоративна композиція «B пошуках цвіту» (1994 рік) та декоративна композиція «Пори року» (1977 рік) віддалені одна від одної в часі, проте демонструють єдину тему - захоплення природою, розуміння багатства флори та фауни рідного краю. Дрібний рисунок рослин органічно покриває прямокутні сторони поверхонь, а вишукана кольорова гама додає ошатності пластиці дрібних форм. Декоративна структура декору вдало підпорядкована формі твору, вирізняється самобутністю, делікатним і злагодженим візерунком. Центральна частина виробу густо вкрита декором, але водночас зберігається певна логіка його розташування: середина зосереджує дрібні елементи, краї - крупніші. Складники декору не суперечать один одному, органічно співіснують і підсилюють загальне образно-асоціативне звучання.

Декоративна композиція «Квіти 3 подорожі» (1900 рік) вражає досконалістю форм, композиційним рішенням, лаконічним, проте напрочуд виразним формотворенням. Подібною за композиційним рішенням $є$ декоративна пластика «Стара колона» (2003 рік), яка диктує ностальгію спогадів і пропонує поштовх думки для осмислення минулого.

Особливою $є$ творча робота Тараса Левківа декоративна пластика «Молитва» (2002 рік), у якій максимально виявилося духовно-релігійне прагнення нашого народу. Акуратно складені догори долоні мають просте композиційне рішення. Вміло використовуючи прийом урізаної кисті, автор поглиблює ідею прохання благословення та величі молитви. Він демонструє молитву як код і однієї людини, і всього народу. Крупна та рельєфна фактура поверхні вкрита біло-сріблястобежевими емалями, які посилюють ідею єднання нижчого з вищим і присутність надії серед усіх.

Звернемо увагу на декоративні пластики «Квіти з майдану-1», «Квіти з майдану-2», «Квіти 3 майдану-3», які $\epsilon$ унікальними та знаковими, суспільно-політично гостро актуальними і художньо-композиційним рішенням напрочуд влучно передають атмосферу події, яка $\epsilon$ максимально значущою для українського народу, є одним із етапів національного утвердження та становлення. Активна жовтогаряча кольорова гама поєднана 3 активним ламано-зубчастим декором поверхні якнайкраще передає напруженість події. Ромбічна верхня частина композиції має вектор руху догори, що підкреслює ідею звільнення, пробудження та спротиву. Тарас Левків уміло вирішив складне завдання - за допомогою трансформації форми та кольору показав перетікання матеріального у духовне та ідеальне.

Висновки. Проаналізувавши творчий шлях відомого львівського художника Тараса Левківа та здійснивши мистецтвознавчий аналіз окремих творів пластики малих форм, можна дійти висновку, що кожен історичний період мав вплив на творчий потенціал кераміста та на формування художньостилістичних особливостей пластики малих форм.

У цій статті зосереджено увагу на такій класифікації творів, яка не вичерпує широкого діапазону творчого доробку автора. Насамперед виділено пластику малих форм 3 антропоморфними мотивами. Зазначено, що важливе місце займає пластика малих форм, в основу якої покладено куб, циліндр. Також виділена група скульптури малих форм, в основі композиційної побудови якої маємо кулю або округлості овоїдної форми.

Твори Тараса Левківа характеризуються особливим відчуттям кольору, в чому виявляється як безпосередній вплив новаторських тенденцій, так і замилування традиційним спадком української народної кераміки. Їм притаманний виразний, тектонічно підпорядкований контрастний колорит, багатство та специфічна пластики глазурованої поверхні. 


\section{СПИСОК ВИКОРИСТАНИХ ДЖЕРЕЛ}

1. Винниченко О. М. Монументально-декоративні композиції Тараса Левківа та Уляни Ярошевич для архітектурнопросторового середовища. Вісник Національного університету «Львівська політехніка». № 674. 2010. С. $164-170$.

2. Голубець О. Магія третього виміру. Скульптурна пластика кінця XIX - початку XXI століття. Львів : Колір ПРО. 2020. $143 \mathrm{c}$.

3. Голубець О. Тарас Левків. Кераміка. Графіка. Інтарсія. Львів. 2007. 127 с.

4. Дуда І. Левків Тарас Богданович. Тернопільський енциклопедичний словник: у 4 т. / редкол.: Г. Яворський та ін. Тернопіль : Видавничо-поліграфічний комбінат «Збруч», 2005. Т. 2. К.-О. С. 334.

5. Левків Тарас Богданович. Кераміка України. К. : Видавничий центр «Логос Україна», 2009. С. 80.

6. Придатко Т. Тарас Левків. Кераміка. Графіка. Інтарсія. Мистецтвознавство України. Львів : «Афіша», 2011. C. 316-325.

\section{REFERENCES}

1. Vynnychenko O. M. Monumentalno-dekoratyvni kompozytsii Tarasa Levkiva ta Uliany Yaroshevych dlia arkhitekturno-prostorovoho seredovyshcha [Monumental and decorative compositions of Taras Levkiv and Ulyana Yaroshevych for the architectural and spatial environment]. Bulletin of the National University "Lviv Polytechnic", 2010, № 674, p. 164-170 [In Ukrainian].

2. Holubets O. Mahiia tretoho vymiru. Skulpturna plastyka kintsia XIX - pochatku XXI stolittia [Magic of the third dimension. Sculptural sculpture of the late XIX - early XXI century]. Lviv : Kolir PRO. 2020. 143 p. [In Ukrainian].

3. Holubets O. Taras Levkiv. Keramika. Hrafika. Intarsiia [Taras Levkiv. Ceramics. Graphics. Intarsia]. Lviv, 2007. 127 p. [In Ukrainian].

4. Duda I. Levkiv Taras Bohdanovych. ernopil encyclopedic dictionary: in 4 volumes. Ternopil : Vydavnycho-polihrafichnyi kombinat "Zbruch", 2005, Vol. 2. K.-O. P. 334 [In Ukrainian].

5. Levkiv Taras Bohdanovych. Ceramics of Ukraine. Kyiv : Vydavnychyi tsentr "Lohos Ukraina”, 2009. P. 80 [In Ukrainian].

6. Prydatko T. Taras Levkiv. Keramika. Hrafika. Intarsiia [Taras Levkiv. Ceramics. Graphics. Intarsia]. Art History of Ukraine. Lviv : “Afisha”, 2011, p. 316-325 [In Ukrainian]. 